\title{
Performance of Anaerobic Co-digestion of Pig Slurry with Pineapple (Ananas comosus) Bio-waste Residues
}

\author{
A. Azevedo ${ }^{1} \cdot$ J. Gominho $^{2} \cdot$ E. Duarte $^{1}$ (C)
}

Received: 24 June 2019 / Accepted: 5 February 2020 / Published online: 27 February 2020

(c) Springer Nature B.V. 2020

\begin{abstract}
Agro-food industries produce large amounts of bio-waste, challenging innovative valorisation strategies in the framework of circular economy principles. Anaerobic digestion technology is an interesting route to stabilise organic matter and produce biogas as a renewable energy source. This paper aimed to study the optimal performance conditions for anaerobic co-digestion (AcoD) of pig slurry with pineapple (Ananas comosus) peel bio-waste. The anaerobic digestion (AD) trials were performed at lab scale, in a continuous stirred reactor, for 16 days' hydraulic retention time in mesophilic conditions $\left(37 \pm 1{ }^{\circ} \mathrm{C}\right)$. Three hydraulic retention time were performed, one for the reference scenario $\left(\mathrm{T}_{0}\right)$ and two for AcoD trials $\left(\mathrm{T}_{1}, \mathrm{~T}_{2}\right)$. Feeding mixtures (20:80; v:v) of pineapple peel liquor and pig slurry, with an OLR of $1.46 \pm 0.04 \mathrm{~g} \mathrm{TVS} \mathrm{L}^{-1}$ reactor day ${ }^{-1}$ were used during $\mathrm{AD} / \mathrm{AcoD}$ trials, presenting high values for soluble chemical oxygen demand and $\mathrm{C} / \mathrm{N}$ ratio. This operational conditions highlight bioenergy recovery up to $0.58 \mathrm{~L} \mathrm{CH}_{4} \mathrm{~g} \mathrm{TVS}_{\text {added }}{ }^{-1}$, in comparison with that obtained with pig slurry substrate $(0.31$ $\mathrm{L} \mathrm{CH}_{4} \mathrm{~g} \mathrm{VS}_{\text {added }}{ }^{-1}$ ). The AD performance showed a total volatile solids and chemical oxygen demand removal efficiency of $23 \%$ to $47 \%$ and $26 \%$ to $48 \%$, comparing $\mathrm{T}_{0}$ with the average of $\mathrm{T}_{1}$ and $\mathrm{T}_{2}$, respectively. The digester stability, evaluated by specific energetic loading rate, was below the limit $\left(0.4 \mathrm{day}^{-1}\right)$ throughout the trials. Pig slurry co-digestion with pineapple peel liquor seems to be a promising approach for potential bioenergy recovery.
\end{abstract}

\section{Graphic Abstract}

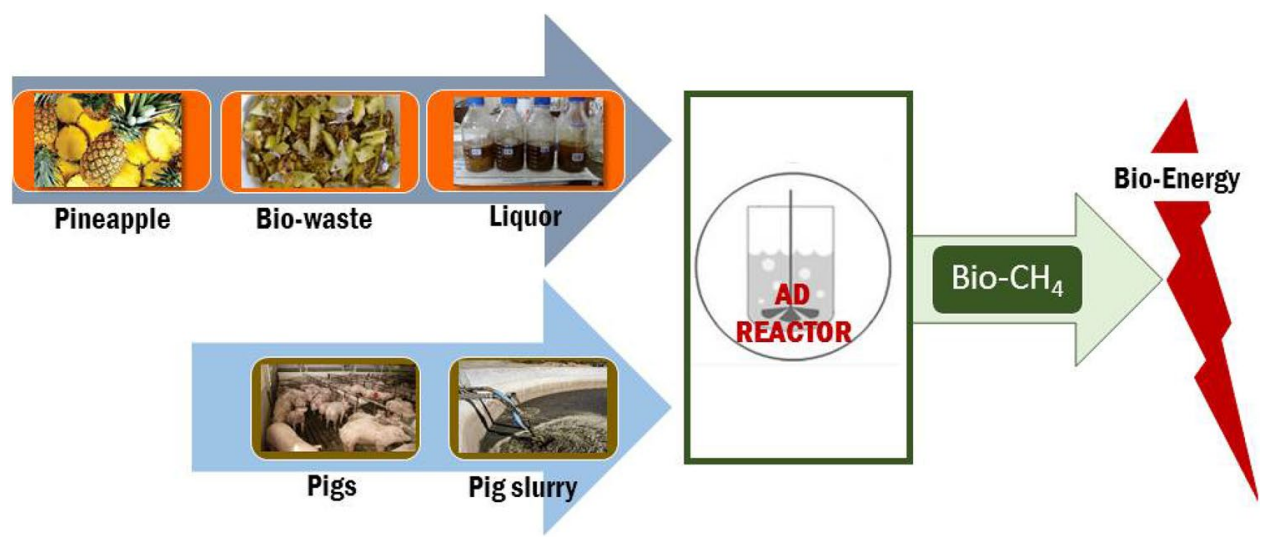

Keywords Biogas · Waste management · Pineapple $\cdot$ Pig slurry $\cdot$ Circular economy

\section{Abbreviations}

AcoD Anaerobic co-digestion

AD Anaerobic digestion

E. Duarte

eduarte@ isa.ulisboa.pt

Extended author information available on the last page of the article
C/N Carbon/nitrogen ratio

GPR Gas production rate

HRT Hydraulic retention time

IA Intermediate alkalinity

OLR Organic loading rate

PA Partial alkalinity 


$\begin{array}{ll}\text { PPL } & \text { Pineapple peel liquor } \\ \text { PS } & \text { Pig slurry } \\ \text { SCOD } & \text { Soluble chemical oxygen demand } \\ \text { SELR } & \text { Specific energetic loading rate } \\ \text { SGP } & \text { Specific gas production } \\ \text { SMP } & \text { Specific methane production } \\ \text { TA } & \text { Total alkalinity } \\ \text { TCOD } & \text { Total chemical oxygen demand } \\ \text { TKN } & \text { Total Kjeldahl nitrogen } \\ \text { TOC } & \text { Total organic carbon } \\ \text { TS } & \text { Total solids } \\ \text { TVS } & \text { Total volatile solids } \\ \text { TSVS } & \text { Total suspended volatile solids }\end{array}$

\section{Statement of Novelty}

- Methane yield upgrade in AcoD trials, using a feedstock (80\% pig slurry:20\% pineapple peel liquor v:v);

- Synergetic effects between $\mathrm{C} / \mathrm{N}$ ratio, SMP and AD efficiency;

- Valorisation of an agro-food bio-waste to bioenergy recovery $\left(\right.$ Bio- $\left.\mathrm{CH}_{4}\right)$.

\section{Introduction}

Livestock production is an important industry sector considering economic and global food security aspects [1]; however, this growth in activity has led to enormous environmental impacts, which have started to threaten the resilience of natural ecosystems [2]. The world production of pig meat increased by $29 \%$ between 2000 and 2016, and it is expected to increase $9.5 \%$ more by 2026 , to reach 127.5 million tons [3]. Livestock waste management is a major challenge due to its pollutant load [4], and swine production already generates a high volume of waste with high pollutant concentrations [5].

In addition, agro-food industries, like the food fruit processing industry, generate large amounts of bio-waste (e.g. peels, barks). Pineapple (Ananas comosus) is the third most produced tropical fruit, after banana and mango [6]. It belongs to the Bromeliaceae family and has a total cultivated area of 1.02 million hectares, with a global production of 24.8 million tons year ${ }^{-1}$, resulting in great quantities of biowaste (peels and rags) [7].

The most innovative environmental management strategy is the potential bioenergy recovery of this bio-waste generated in the food processing chain, as feedstocks for promoting the circular bioeconomy concept. Based on this approach, anaerobic digestion (AD) technology is an interesting route to combine these two substrates (with different physical/chemical characteristics), to produce renewable biofuels $\left(\mathrm{Bio}-\mathrm{CH}_{4}\right)$ and improve the stabilisation of pig slurry organic matter, respectively [8]. The biogas obtained can be used to produce electric and thermic energy, to inject into the natural gas network (when purified), or as a biofuel in transport, among other applications $[9,10]$.

The production of this renewable biofuel can bring many social and environmental benefits, such as a reduction of the organic matter content; reduction of greenhouse gas emissions; global warming mitigation; and a reduction of dependence on fossil fuels, among others [11]. Besides that, the solid fraction of the digestate produced during $\mathrm{AD}$ can be applied as a biofertiliser in agricultural practices [12].

Different researchers have studied the use of different co-substrates in the AD process in order to increase the methane content in biogas; e.g. agro-food fruit bio-waste (banana peels, citrus peels) [13, 14], biomass from energy crops (Cynara, elephant grass) [15, 16], and agricultural and municipal waste [17]. Since pineapple peel is rich in carbohydrates (cellulose, hemicellulose and free sugars) it is a potential co-substrate in $\mathrm{AD}$ [18]. In addition, those substrates increase the stability of the AD process, enhancing the nutrient balance,ameliorate microorganisms' synergistic effects; and help to mitigate greenhouse gas emissions [19].

The aim of this study was to assess the influence of pineapple peel liquor as a co-substrate to enhance $\mathrm{AD}$ of pig slurry from the fattening/finishing phase, in a continuous stirred reactor at mesophilic conditions $\left(37 \pm 1^{\circ} \mathrm{C}\right)$, and a hydraulic retention time (HRT) of 16 days. For these purposes, the liquor from pineapple peel used as co-substrate was fully characterised (chemically, physically and energetically), and the Bio- $\mathrm{CH}_{4}$ content evaluated in $\mathrm{AD}$ and $\mathrm{AcoD}$ trials.

\section{Experimental Sections}

\section{Materials}

\section{Pig Slurry}

Pig slurry (PS) was provided by a swine livestock facility located $90 \mathrm{~km}$ from Lisbon in the Alentejo region, Portugal, with a total area of $1050.320 \mathrm{~m}^{2}$ and capacity for 900 sows, with 3924 fattening places. The production cycle consists of: gestation-maternity-lactation; post-weaning nursery; and fattening/finishing. The slurry management system of the farm includes a storage tank, solid-liquid separation of slurries, and a lagoon system. Samples were collected from the fattening slurry storage tank for utilisation in trials. The samples had remnants of grains and coarse material, so the slurries were sieved with a strainer with a mesh size of $2 \mathrm{~mm}$ to remove 
these residues. After sieving, the remaining liquid fractions were stored at $4{ }^{\circ} \mathrm{C}$.

\section{Pineapple peel}

Pineapple residues from 18 fruits were collected from the 'Time Out Market Lisboa', Portugal where 'Compal Frutólogica' makes on the spot and serves directly to the customer $100 \%$ juices of fruit selected from the country's best growers. The fresh residues were separated into two different fractions, pineapple crown (PC) and pineapple peel (PP), weighed and dried in an oven at $80^{\circ} \mathrm{C}$, until achieving a constant weight. Further, the PP residues were milled in a knife mill (Retsch SM 2000) with an output sieve of 6 mesh and stored in a plastic bag for future use.

\section{Methods}

\section{Pineapple Peel Liquor}

The PP residue was thermal-hydrolysed using a liquid to dried solid ratio of $10: 1$ for $5 \mathrm{~min}$ at $120^{\circ} \mathrm{C}$ and 1.08 bar.

The pre-treatment was conducted in an autoclave (Uniclave 88) with capacity for 24 flasks of $1 \mathrm{~L}$ and a power of $6 \mathrm{~kW}$. Afterwards, the pineapple peel liquor (PPL) was sieved with a strainer with a mesh size of $2 \mathrm{~mm}$ to extract solid residues. The volume of the liquid fraction was registered to calculate the liquor efficiency recovery reported as a percentage of fresh pineapple fruit weight. The PPL was stored at $4{ }^{\circ} \mathrm{C}$ for utilisation as co-substrate, while the solid fraction was disposed of.

\section{Chemical and Thermal Characterisation}

Chemical analysis of the PP was performed according to standard methods: ash content by TAPPI 211 om- 02 , and extractives content by successive extraction with dichloromethane, ethanol and water (TAPPI $204 \mathrm{~cm}-97$ ). Klason lignin was quantified using TAPPI $222 \mathrm{om}-02$, and the acid-soluble lignin determined by absorbance at $205 \mathrm{~nm}$ in the hydrolysate (TAPPI UM 205 om-93). The holocellulose and its $\alpha$-cellulose and hemicellulose fractions were analysed according to Rowell [20]. Mineral composition (Na, K, Mg, P, S, Fe, Cu, Zn, Mn, B) was determined using a flame atomic absorption spectrophotometer (AnalytikJena multi EA 4000), and the higher heating value (HHV) was determined based on ASTM D-2015-66.

\section{Experimental Setup}

\section{Feeding Mixtures}

During the reference scenario $\left(\mathrm{T}_{0}\right)$, the $\mathrm{AD}$ reactor was only fed with PS from the fattening/finishing phase, after steady state conditions had been achieved. For the co-digestion experiments, two trials $\left(\mathrm{T}_{1}\right.$ and $\left.\mathrm{T}_{2}\right)$ and a PPL to PS ratio of 20:80 were used (Table 1).

\section{Feeding Mixture and Digestate Characterisation}

The following feeding mixture parameters were characterised in accordance with the Standard Methods for the Examination of Water and Wastewater [21]: $\mathrm{pH}$, electrical conductivity (EC); total solids (TS); total volatile solids (TVS); total volatile suspended solids (TVSS); total chemical oxygen demand (TCOD); soluble chemical oxygen demand (SCOD) and total Kjeldahl nitrogen (TKN). Total organic carbon (TOC) was determined by following the method described by Cuetos et al. [22], and compared with some measurements obtained using a carbon analyser (TOC, Analytikjena Multi EA 4000), by performing combustion of the sample at $1200{ }^{\circ} \mathrm{C}$. The $\mathrm{C} / \mathrm{N}$ ratio was calculated by dividing the TOC by the TKN. Total alkalinity (TA) and partial alkalinity (PA) were determined by a titration method at $\mathrm{pH} 4.3$ and at 5.75, respectively, and the intermediate alkalinity (IA) by the difference between TA and PA [21].

\section{Lab-Scale Experiment}

The anaerobic co-digestion (AcoD) experiment was performed during three trials $\left(\mathrm{T}_{0}, \mathrm{~T}_{1}\right.$ and $\left.\mathrm{T}_{2}\right)$ in a mesophilic temperature range $\left(37 \pm 1^{\circ} \mathrm{C}\right)$ with an HRT of 16 days. The reactor was a CSTR (continuous stirring tank reactor) with a working volume of $4.8 \mathrm{~L}$, controlled by computer software. The temperature inside the reactor was maintained by a heating system and recorded along the trials. The feeding mixture was homogenized by a mechanical stirrer (model VELP Scientifica, $50 \mathrm{rpm}, 60 \mathrm{~W}$ ) and added to the digester using a peristaltic pump (model Watson Marlow, $120 \mathrm{rpm}$ ). A flowmeter was used to control the biogas production (model MilliGascounter MGC-1 V3.0, Ritter, Germany) as illustrated in Fig. 1. Temperature, $\mathrm{pH}$ and EC of the inlet and outlet flows and biogas production were measured daily.

\section{Operational Parameters}

During the experiment, several parameters were determined in order to study the AD process: gas production rate (GPR);

Table 1 Experimental assay setup configuration

\begin{tabular}{llll}
\hline Experimental trials & $\begin{array}{l}\text { HRT } \\
\text { (days) }\end{array}$ & Temperature $\left({ }^{\circ} \mathrm{C}\right)$ & $\begin{array}{l}\text { Feeding mixture } \\
\text { (PPL:PS v:v; \% })\end{array}$ \\
\hline $\mathrm{T}_{0}$-reference trial & 16 & $37 \pm 1$ & $0: 100$ \\
$\mathrm{~T}_{1}$-first co-digestion & 16 & $37 \pm 1$ & $20: 80$ \\
trial & & $37 \pm 1$ & $20: 80$ \\
$\begin{array}{l}\mathrm{T}_{2} \text { - second co-digestion } 16 \\
\text { trial }\end{array}$ & & \\
\hline
\end{tabular}


organic loading rate (OLR); specific gas production (SGP) and specific methane production (SMP). Biogas quality (in terms of $\mathrm{CH}_{4}$ and $\mathrm{CO}_{2}$ ) was measured on a weekly basis, using an LMSxi Multifunction Landfill Gas Analyser. The digester was continuously monitored by on-site $\mathrm{pH}$ probe and by periodical analysis of TA and PA. To evaluate the reactor stability during the trials, the indicator IA/PA proposed by Astals et al. [23] and the specific energetic loading rate (SELR) [24] were determined. Regarding the reactor performance, TVS and TCOD removal efficiency were calculated at the end of each trial and correlated with the SMP values achieved.

\section{Results and Discussion}

The summative chemical and mineral composition of PP is presented in Table 2. Ash represented $4.1 \%$ of the PP, while total extractives accounted for $56.2 \%$ (mainly constituted by polar compounds attained by ethanol (38.8\%) and water extractions $(16.5 \%)$ ), total lignin $7.1 \%$ and holocellulose (hemicelluloses + cellulose) $33.7 \%$.

The ash content in PP is much lower than in other fruit peels such pawpaw $(10.2 \%)$, banana $(12.4 \%)$ or pomegranate (6.1\%), but higher than in apple (1.4\%) and mango (3.2\%) peels [25]. Pardo et al. [26] studied different fractions from pineapple residues and determined that the ash represented $3.0 \%$ in the pulp, $7.4 \%$ in the leaf bracts, $1.5 \%$ in the shells and $1.3 \%$ in the core.

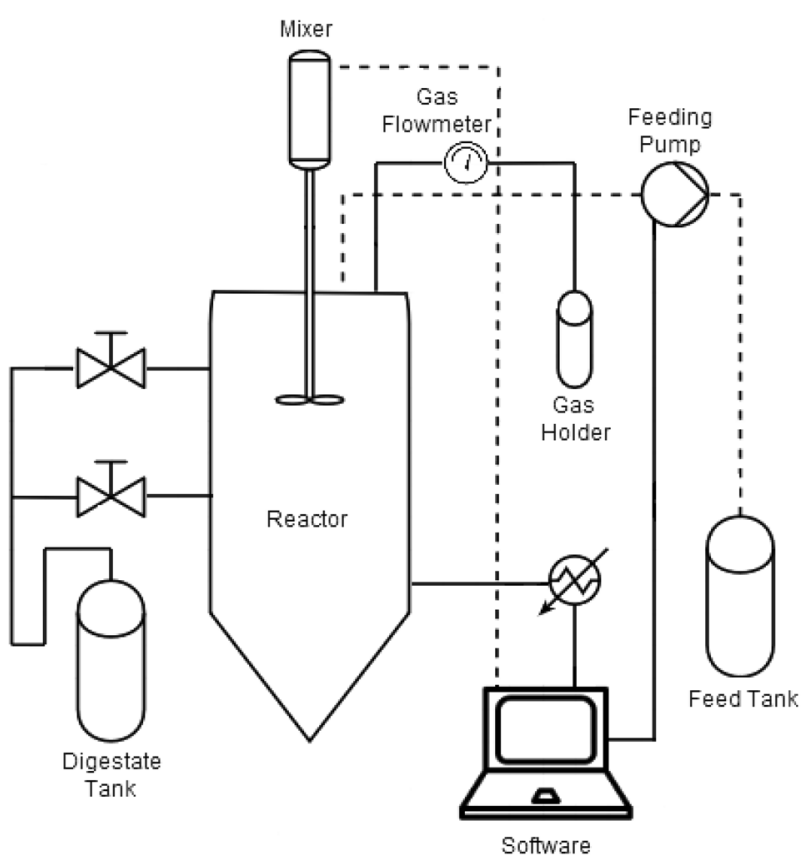

Fig. 1 Schematic diagram of biogas unit used for experimental assays
Table 2 Summative chemical composition and mineral composition of pineapple peel

\begin{tabular}{|c|c|c|c|}
\hline $\begin{array}{l}\text { Component } \\
\text { (Mass fraction, \%) }\end{array}$ & & $\begin{array}{l}\text { Mineral content } \\
\text { (mg per } 100 \mathrm{~g} \\
\mathrm{DM})\end{array}$ & \\
\hline Ash & 4.1 & $\mathrm{Na}$ & 16.4 \\
\hline Total extractives & 56.2 & $\mathrm{~K}$ & 17,043 \\
\hline Dichloromethane & 0.9 & $\mathrm{Mg}$ & 85 \\
\hline Ethanol & 38.8 & $\mathrm{P}$ & 153 \\
\hline Water & 16.5 & $\mathrm{~S}$ & 137 \\
\hline Total lignin & 7.1 & $\mathrm{Fe}$ & 4.4 \\
\hline Klason lignin & 5.6 & $\mathrm{Cu}$ & 0.8 \\
\hline Soluble lignin & 1.5 & $\mathrm{Zn}$ & 1.6 \\
\hline Holocellulose & 33.7 & Mn & 4.4 \\
\hline$\alpha$-Cellulose & 10.9 & B & 0.7 \\
\hline Hemicellulose & 22.8 & & \\
\hline
\end{tabular}

$D M$ dry matter

Regarding the total lignin content, the value attained here (7.1\%) was lower than the $13.8 \%$ and $10.0 \%$ reported for leaf bracts and shell fractions, but slightly higher than the $5.8 \%$ for the core fraction [26]. The same study revealed substantially more carbohydrate content in pineapple residues, ranging from $53.0 \%$ (core) to $69.2 \%$ (shell) when compared to the value reported here (33.7\%). Lukitawesa et al. [27] found $19.0 \%$ carbohydrate content in citrus peel.

$\mathrm{PP}$ is rich in $\mathrm{K}\left(17,043 \mathrm{mg} 100 \mathrm{~g}^{-1}\right)$ and $\mathrm{P}(153 \mathrm{mg}$ $\left.100 \mathrm{~g}^{-1}\right)$. Morais et al. [28] reported $1349.5 \mathrm{mg}$ per $100 \mathrm{~g}$ for K, and Romelle et al. [25] $6.5 \mathrm{mg}$ per $100 \mathrm{~g}$ for $\mathrm{Zn}$ and $5.3 \mathrm{mg}$ per $100 \mathrm{~g}$ for $\mathrm{Mn}$.

The proximate analysis and calorific value of PP used in this experiment are shown in Table 3. The mean HHV was $17.7 \mathrm{MJ} \mathrm{kg}^{-1}$ that is in the range of values reported for other fruit peels (16.2 to $19.6 \mathrm{MJ} \mathrm{kg}^{-1}$ ) [29]. The proximate analysis of PP showed a mean of $66.0 \%$ volatile matter. Lukitawesa et al. [27] reported $23.1 \%$ for volatile solids and Carvalho et al. [30] 45-51 g/L for citrus peels (dry basis).

\section{Feeding Mixture and Digestate Characteristics}

The results obtained during the experimental trials are presented in Table 4.

Table 3 Proximate analysis and calorific value of pineapple peel

\begin{tabular}{lr}
\hline Moisture (\%, dry basis) & 13.0 \\
Ash (\%, dry basis) & 4.1 \\
Volatile matter (\%, dry basis) & 66.0 \\
Fixed carbon (\%, dry basis) & 16.9 \\
High calorific value $\left(\mathrm{MJ} \mathrm{kg}^{-1}\right)$ & 17.7 \\
\hline
\end{tabular}


Analysing Table 4, and according to trial $\mathrm{T}_{0}$, the PS inlet values showed an average $\mathrm{pH}$ of $7.6 \pm 0.1$, which is in accordance with the range expected for this type of substrate [31] and referred to as ideal in the literature for AD processes [32,33]. The slight decrease of $\mathrm{pH}$ average value (7.2 \pm 0.2 ), during AcoD is probably due the presence of biodegradable sugars. The TVS/TS ratio increased, from the reference trial $\left(\mathrm{T}_{0}\right)$ to the co-digestion trials $\left(\mathrm{T}_{1}\right.$ and $\left.\mathrm{T}_{2}\right)$ (64.5\% to $71 \%$ and $72 \%$ ) respectively. During the AcoD trials $\left(\mathrm{T}_{1}\right.$ and $\left.\mathrm{T}_{2}\right)$, the feeding mixture was prepared by combining PPL and PS (20:80, v/v PPL:PS) prepared under the selected conditions as previously described. This procedure improved the availability of organic matter as shown by the SCOD/COD ratio twice that obtained during $\mathrm{T}_{0}$ (Table 4). This aspect is very relevant as the low solubilisation degree of PS organic matter is responsible for the low methane yields generally achieved. The addition of the pineapple peel liquor (PPL) originated a decrease of the mixture nitrogen compounds, more specifically, a $44 \%$ decrease of TKN, from $\mathrm{T} 0$ to $\mathrm{T} 1$ and T2. Due to the decrease of TKN present in the mixture, the $\mathrm{C} / \mathrm{N}$ ratio improves by doubling the value from the initial trial (T0) value to the third trial, $\mathrm{T} 2$. The improvement of this value generates higher methane yields in the trials following $\mathrm{T} 0$, which contributes to balancing the feedstock composition, allowing better performance of the AD biotechnological process [34].

\section{Anaerobic Digestion Stability and Performance}

In order to assess the process performance and stability, different AD experiments with PS as a mono-substrate and PS with addition of PPL as feedstock's for co-digestion were performed at similar OLR and hydraulic retention times (HRT). Figure 2 shows the average gas production rates
(GPR) correlated with the OLR's applied in the reference scenario (T0) and in the co-digestion trials (T1 and T2).

These data allow seeking the influence of the co-substrate incorporation over the AD process and biogas production. The average daily biogas production rate during the reference trial was approximately $0.69 \pm 0.15 \mathrm{~L} \mathrm{~L}^{-1}$ reactor, in comparison with the values achieved for T1 and T2 $(1.15 \pm 0.03 \mathrm{~L}$ $\mathrm{L}^{-1}$ reactor and $1.17 \pm 0.03 \mathrm{~L} \mathrm{~L}^{-1}$ reactor), respectively. This means an increment of $67 \%$ in the GPR from the reference trial to the first co-digestion trial, and $70 \%$ in the last trial. These results are also aligned with those reported by Duan et al. [35] for single treatment of PS, attending to the HRT of 16 days set in the study presented. The results obtained in the CoAD trials with PPL showed an improvement of gas productions rate in comparison with other studies referred in the literature [36].

The digestate $\mathrm{pH}$ and SMP were monitored and correlated with IA/PA indicator and SELR to evaluate the stability of AD/AcoD process (Fig. 3).

The operational parameters monitored during the trials, presented in Table 5, clearly illustrate the enhancement of bioconversion during the co-digestion process. To corroborate this statement, we can refer to the increase in GPR (around 70\%) between the reference trial and the co-digestion trials.

The SGP (Table 5) in the reference trial was $0.44 \mathrm{~L} \mathrm{~g}$ $\mathrm{VS}^{-1}$; it was $0.80 \mathrm{~L} \mathrm{~g} \mathrm{VS}^{-1}$ during the co-digestion trials (that corresponds to an increase of almost 82\%). The same happened for the SMP, with an increase of almost $84 \%$ (from $0.31 \pm 0.05$ to $0.57 \pm 0.07 \mathrm{~L} \mathrm{~g} \mathrm{VS}^{-1}$ ).

During the reference trial, the reduction in TVS was only $23 \%$; in the co-digestion trials it was almost $47 \%$, which means an increase of $103 \%$. The reduction in TCOD in the
Table 4 Feeding mixture and digestate characterisation

\begin{tabular}{|c|c|c|c|c|c|c|}
\hline \multirow[t]{2}{*}{ Characteristics } & \multicolumn{2}{|c|}{$\begin{array}{l}\mathrm{T}_{0} \\
(0: 100, \mathrm{v} / \mathrm{v} \text { PPL:PS })\end{array}$} & \multicolumn{2}{|c|}{$\begin{array}{l}\mathrm{T}_{1} \\
(20: 80, \mathrm{v} / \mathrm{v} \text { PPL:PS) }\end{array}$} & \multicolumn{2}{|c|}{$\begin{array}{l}\mathrm{T}_{2} \\
(20: 80, \mathrm{v} / \mathrm{v} \text { PPL:PS) }\end{array}$} \\
\hline & Influent & Digestate & Influent & Digestate & Influent & Digestate \\
\hline $\mathrm{pH}$ & $7.6 \pm 0.1$ & $7.8 \pm 0.1$ & $7.2 \pm 0.2$ & $7.8 \pm 0.04$ & $7.1 \pm 0.1$ & $7.9 \pm 0.03$ \\
\hline $\mathrm{EC}\left(\mathrm{mS} \mathrm{cm}^{-1}\right)$ & $15.1 \pm 6.6$ & $17.9 \pm 2.1$ & $18.1 \pm 0.4$ & $22.9 \pm 1.2$ & $18.1 \pm 0.3$ & $21.2 \pm 0.4$ \\
\hline $\mathrm{TS}\left(\mathrm{g} \mathrm{L}^{-1}\right)$ & $37.2 \pm 0.03$ & 30.3 & $32.6 \pm 0.02$ & 22.2 & $31.8 \pm 0.01$ & 21.1 \\
\hline TVS $\left(\mathrm{g} \mathrm{L}^{-1}\right)$ & $24.0 \pm 0.02$ & 18.4 & $23.2 \pm 0.02$ & 12.3 & $22.9 \pm 0.01$ & 12.1 \\
\hline TVS/TS (\%) & 64.5 & 60.7 & 71.2 & 55.4 & 72.0 & 57.3 \\
\hline $\operatorname{TVSS}\left(\mathrm{g} \mathrm{L}^{-1}\right)$ & - & 8.12 & - & 8.81 & - & 8.52 \\
\hline $\operatorname{TCOD}\left(\mathrm{g} \mathrm{L}^{-1}\right)$ & 38.4 & 28.3 & 47.8 & 25.0 & 46.1 & 24.2 \\
\hline $\operatorname{SCOD}\left(\mathrm{g} \mathrm{L}^{-1}\right)$ & 10.3 & 7.0 & 24.9 & 6.7 & 24.0 & 5.8 \\
\hline SCOD/TCOD (\%) & 26.8 & - & 52.1 & - & 52.1 & - \\
\hline $\operatorname{TOC}\left(\mathrm{g} \mathrm{L}^{-1}\right)$ & 13.9 & - & 13.5 & - & 13.4 & - \\
\hline TKN $\left(\mathrm{g} \mathrm{L}^{-1}\right)$ & 2.6 & - & 1.5 & - & 1.4 & - \\
\hline $\mathrm{C} / \mathrm{N}$ & 5 & - & 9 & - & 10 & - \\
\hline OLR $\left(\right.$ g TVS L L $^{-1} \mathrm{~d}^{-1}$ ) & $1.50 \pm 0.02$ & - & $1.45 \pm 0.02$ & - & $1.44 \pm 0.01$ & - \\
\hline
\end{tabular}


- GPR o OLR

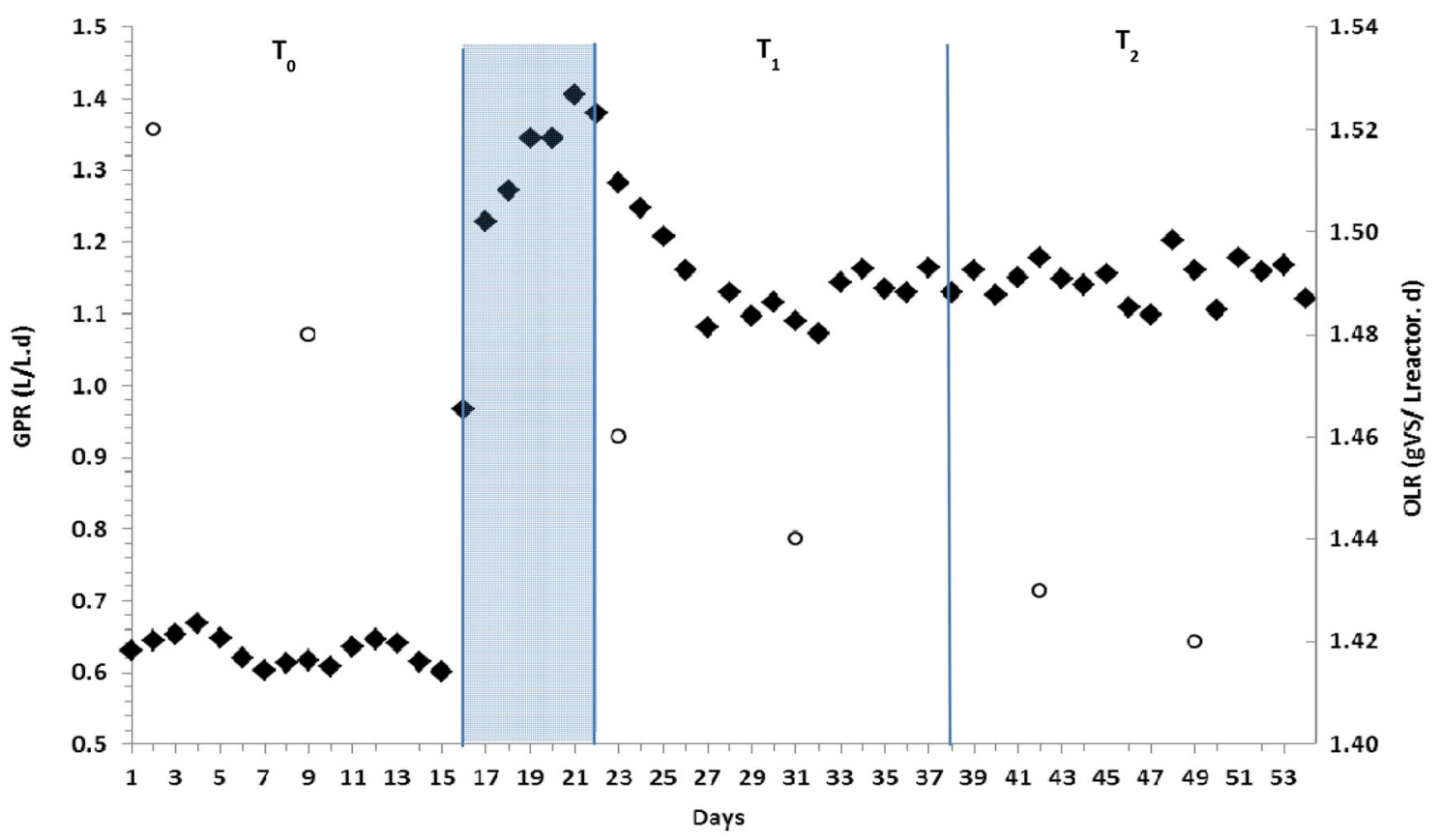

Fig. 2 Variation of the gas production rate and the organic loading rate in the reference scenario (T0) and in the co-digestion trials (T1 and T2)

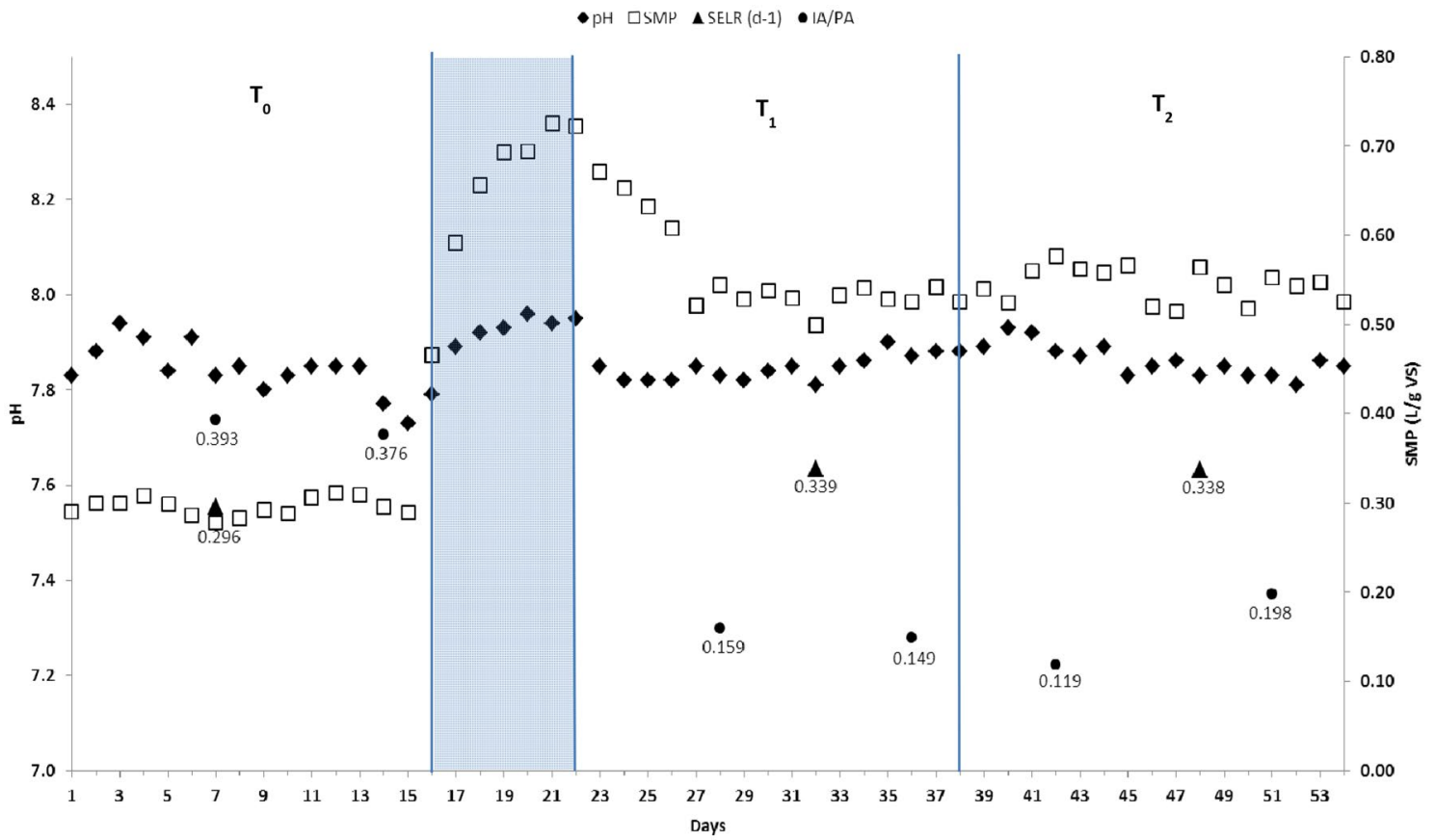

Fig. 3 Influence of the different feedstock composition over the digester control parameters: $\mathrm{pH}, \mathrm{SMP}$, IA/PA ratio and SELR

reference trial was $26 \%$; in the following trials it was $48 \%$, representing an increase of $82 \%$ (Table 5).
The stability of an AD process, in terms of VFA accumulation and alkalinity, depends mainly on the type of substrate used and relative percentages of co-substrate. The alkalinity 
Table 5 Operational parameters during the AcoD trials

\begin{tabular}{llll}
\hline Operational parameters & $\begin{array}{l}\mathrm{T}_{0} \\
(0: 100, \mathrm{v} / \mathrm{v} \text { PPL:PS })\end{array}$ & $\begin{array}{l}\mathrm{T}_{1} \\
(20: 80, \mathrm{v} / \mathrm{v} \text { PPL:PS })\end{array}$ & $\begin{array}{l}\mathrm{T}_{2} \\
(20: 80, \mathrm{v} / \mathrm{v} \text { PPL:PS })\end{array}$ \\
\hline GPR $\left(\mathrm{L} \mathrm{L}^{-1}\right.$ day $\left.^{-1}\right)$ & $0.69 \pm 0.09$ & $1.15 \pm 0.08$ & $1.17 \pm 0.03$ \\
Biogas quality $\left(\% \mathrm{CH}_{4}\right)$ & 72 & 69 & 68 \\
SGP $\left(\mathrm{L}_{\mathrm{Biogas}} \mathrm{g} \mathrm{VS}^{-1}\right)$ & $0.44 \pm 0.06$ & $0.80 \pm 0.06$ & $0.80 \pm 0.02$ \\
$\mathrm{SMP}\left(\mathrm{L}_{\mathrm{CH} 4} \mathrm{~g} \mathrm{VS}^{-1}\right)$ & $0.31 \pm 0.05$ & $0.57 \pm 0.07$ & $0.54 \pm 0.02$ \\
TVS reduction $(\%)$ & 23.3 & 47.0 & 47.2 \\
TCOD reduction $(\%)$ & 26.3 & 47.8 & 47.5 \\
TA $\left(\mathrm{mg} \mathrm{CaCO}_{3} \mathrm{~L}^{-1}\right)$ & 7886 & 12,080 & 10,786 \\
PA & 5730 & 10,468 & 9306 \\
IA & 2156 & 1612 & 1480 \\
IA/PA ratio & $0.376 \pm 0.012$ & $0.154 \pm 0.007$ & $0.159 \pm 0.056$ \\
SELR $\left(\right.$ day $\left.^{-1}\right)$ & 0.296 & 0.339 & 0.338 \\
\hline
\end{tabular}

ratio contributes for the buffer capacity of the bioreactor content [37]. A decrease in the buffering capacity caused by the accumulation of VFAs comes earlier than the $\mathrm{pH}$ decrease. Therefore, the IA/PA ratio is a reliable parameter to monitoring AD process imbalance. The recommended IA/ PA ratio for a stable process is below 0.4 [38].

The parameters analysed to evaluate the AD reactor stability, during the experimental trials were IA/PA ratio and SELR. The IA/PA values observed during the AD/AcoD trials $(0.376 \pm 0.012 ; 0.154 \pm 0.007$ and $0.159 \pm 0.056)$ were always below than the lower limit advisable for assuring stable process conditions [38]. According to Evans et al. [24], the limit value for SELR is 0.4 day $^{-1}$. A SELR value higher than 0.4 day $^{-1}$ indicates instability among the microbial consortia biomass and feeding mixture loading. In this experiment, the reference trial SELR value was 0.296 day $^{-1}$, and during the co-digestion trials it was 0.339 day $^{-1}$, indicating the stability of the AD process and the possibility of the OLR increment.

\section{Conclusions}

The results of this study highlight the potential use of PP bio-waste as a biomass source for bioenergy recovery. A stable process operation was observed at an OLR of up to $1.50 \pm 0.02 \mathrm{~g} \mathrm{VS} \mathrm{L}^{-1} \mathrm{day}^{-1}$, with a highest biogas rate production achieved of $1.17 \pm 0.03 \mathrm{~L} \mathrm{~L}^{-1} \mathrm{day}^{-1}$ and an HRT of 16 days. The highest efficiency rate regarding the specific methane yields was $0.57 \pm 0.07 \mathrm{~L} \mathrm{CH}_{4} \mathrm{~g} \mathrm{VS}^{-1}$, at an OLR of $1.45 \pm 0.02 \mathrm{~g} \mathrm{VS} \mathrm{L}^{-1}$, due to PPL addition in AcoD trials. Biogas production from PS (80\%) with PPL (20\%) in the CSTR pilot scale AD system and an HRT of 16 days revealed high efficiency: biogas yield of $0.80 \mathrm{~L} \mathrm{~g} \mathrm{TVS}_{\text {added }}{ }^{-1}$, TVS and COD removal of $47 \%$ and $48 \%$, respectively, were achieved in the AcoD trials $\left(\mathrm{T}_{1}\right.$ and $\left.\mathrm{T}_{2}\right)$. Co-digestion of PS and pineapple waste has a synergistic effect, which improves the biodegradation of feedstock. This effect resulted in a higher methane yield than input of PS alone to the digester. In particular, regarding Portuguese pig livestock units that face a high demand for the waste management of manure, these results can contribute to an increase in the sector's sustainability. Through the adoption of slurry segregation, using a slurry storage tank from the fattening/finishing phase without solid/liquid separation, co-digestion with PPL could be a very effective method to upgrade the performance of AD process technology.

PP bio-waste residue is a promising AcoD substrate that contributes to the valorisation of agro-food bio-waste for bioenergy recovery $\left(\mathrm{Bio}-\mathrm{CH}_{4}\right)$ in the framework of circular economy principles.

Acknowledgements Authors acknowledge the national funding FCT (Fundação para a Ciência e Tecnologia, Portugal), for the financial support to the following research units: the Forest Research Center (CEF), under UID/AGR/00239/2019 project, and Linking Landscape, Environment, Agriculture and Food (LEAF), under UID/AGR/04129/2019 project.

\section{References}

1. Martinho, D.: The Agricultural Economics of the 21st Century. Springer, Cham (2015)

2. Zhou, X., Li, Q., Zhang, Y., Gu, Y.: Effect of hidrotermal pretreatment on Miscanthus anaerobic digestor. Bioresource Technol. 224, 721-726 (2017). https://doi.org/10.1016/j.biortech.2016.10.085

3. Roppa, L.: Revista "Suinicultura", "Desafios e Oportunidades para a Produção de Carnes nos Próximos 10 Anos"; n 119 (2018)

4. Tullo, E., Finzi, A., Guarino, M.: Review: environmental impact of livestock farming and precision livestock farming as a mitigation strategy. Sci. Total Environ. 650, 2751-2760 (2019). https:// doi.org/10.1016/j.scitotenv.2018.10.018

5. Giongo, A., Bortoli, M., De Prá, M.C., Veruck, M., Kunz, A.: Swine wastewater nitrogen removal at different $\mathrm{C} / \mathrm{N}$ ratios using the modified Ludzack-Ettinger process. Eng. Agric. 4430, 
968-977 (2018). https://doi.org/10.1590/1809-4430-eng.agric .v38n6p968-977/2018

6. Zhang, J.S., Liu, J., Ming, R.: Genomic analyses of the CAM plant pineapple. J. Exp. Bot. 65, 3395-3404 (2014). https://doi. org/10.1093/jxb/eru101

7. Ming, R., Van Buren, R., Wai, C.M., Tang, H.B., Schatz, M.C., Bowers, J.E., Lyons, E., Wang, M.L., Chen, J., Biggers, E., Zhang, J.S., Huang, L.X., Zhang, L.M., Miao, W.J., Zhang, J., Ye, Z.Y., Miao, C.Y., Lin, Z.C., Wang, H., Zhou, H.Y., Yim, W.C., Priest, H.D., Zheng, C.F., Woodhouse, M., Edger, P.P., Guyot, R., Guo, H.B., Guo, H., Zheng, G.Y., Singh, R., Sharma, A., Min, X.J., Zheng, Y., Lee, H.Y., Gurtowski, J., Sedlazeck, F.J., Harkess, A., McKain, M.R., Liao, Z.Y., Fang, J.P., Liu, J., Zhang, X.D., Zhang, Q., Hu, W.C., Qin, Y., Wang, K., Chen, L.Y., Shirley, N., Lin, Y.R., Liu, L.Y., Hernandez, A.G., Wright, C.L., Bulone, V., Tuskan, G.A., Heath, K., Zee, F., Moore, P.H., Sunkar, R., Leebens-Mack, J.H., Mockler, T., Bennetzen, J.L., Freeling, M., Sankoff, D., Paterson, A.H., Zhu, X.G., Yang, X.H., Smith, J.A.C., Cushman, J.C., Paull, R.E., Yu, Q.Y.: The pineapple genome and the evolution of CAM photosynthesis. Nat. Genet. 47, 1435-1442 (2015). https://doi.org/10.1038/ng.3435

8. Bauer, F., Hulteberg, C., Persson, T., Tamm, D.: Biogas upgrading-review of commercial technologies (2013)

9. Ryckebosch, E., Drouillon, M., Vervaeren, H.: Techniques for transformation of biogas to biomethane. Biomass Bioenerg. 35, 1633-1645 (2011). https://doi.org/10.1016/j.biomb ioe.2011.02.033

10. Patterson, T., Esteves, S., Dinsdale, R., Guwy, A.: An evaluation of the policy and techno-economic factors affecting the potential for biogas upgrading for transport fuel use in the UK. Energ. Policy 39, 1806-1816 (2011). https://doi.org/10.1016/j.enpol 2011.01.017

11. Baciocchi, R., Carnevale, E., Costa, G., Gavasci, R., Lombardi, L., Olivieri, T., Zanchi, L., Zingaretti, D.: Performance of a biogas upgrading process based on alkali absorption with regeneration using air pollution control residues. Waste Manag. 33(12), 26942705 (2013). https://doi.org/10.1016/j.wasman.2013.08.022

12. Khalid, A., Arshad, M., Anjum, M., Mahmood, T., Dawson, L.: The anaerobic digestion of solid organic waste. Waste Manag. 31, 1737-1744 (2011). https://doi.org/10.1016/j.wasman.2011.03.021

13. Martínez-Ruano, J.A., Caballero-Galván, A.S., Restrepo-Serna, D.L., Cardona, C.A.: Techno-economic and environmental assessment of biogas production from banana peel (Musa paradisiaca) in a biorefinery concept. Environ. Sci. Pollut. R 25, 35971-35980 (2018). https://doi.org/10.1007/s11356-018-1848-y

14. Martínez, E.J., Rosas, J.G., Sotres, A., Moran, A., Cara, J., Sánchez, M.E., Xiomar, G.: Codigestion of sludge and citrus peel wastes: Evaluating the effect of biochar addition on microbial communities. Biochem. Eng. J. 137, 314-325 (2018). https://doi. org/10.1016/j.bej.2018.06.010

15. Oliveira, I., Gominho, J., Diberardino, S., Duarte, E.: Characterization of Cynara cardunculus L stalks and their suitability for biogas production. Ind. Crops Prod. 40, 318-323 (2012). https:// doi.org/10.1016/j.indcrop.2012.03.029

16. Carvalho, A.R., Fragoso, R., Gominho, J., Saraiva, A., Costa, R., Duarte, E.: Water-energy nexus: anaerobic co-digestion with elephant grass hydrolyzate. J. Environ. Manag. 181, 48-53 (2016). https://doi.org/10.1016/j.jenvman.2016.06.012

17. Tasnim, F., Iqbal, S.A., Chowdhury, A.R.: Biogas production from anaerobic co-digestion of cow manure with kitchen waste and Water Hyacinth. Renew. Energ. 109, 434-439 (2017). https://doi. org/10.1016/j.renene.2017.03.044

18. Rani, D.S., Nand, K.: Ensilage of pineapple processing waste for methane generation. Waste manag. 24, 523-528 (2004). https:// doi.org/10.1016/j.wasman.2003.10.010
19. Henard, C.A., Smith, H.K., Guarnieri, M.T.: Phosphoketolase overexpression increases biomass and lipid yield from methane in an obligate methanotrophic biocatalyst. Metab. Eng. 41, 152-158 (2017). https://doi.org/10.1016/j.ymben.2017.03.007

20. Rowell, R.M.: Handbook of Wood Chemistry and Wood Composites, 2nd edn. CRC Press, Florida (2012)

21. APHA: Standard Methods for the Examination of Water and Wastewater, 2nd ed. Washington, DC (2012)

22. Cuetos, M.J., Fernández, C., Gómez, X., Morán, A.: Anaerobic co-digestion of swine manure with energy crop residues. Biotechnol. Bioproc. Eng. 16(5), 1044-1052 (2011). https://doi. org/10.1007/s12257-011-0117-4

23. Astals, S., Nolla-Ardèvol, V., Mata-Alvarez, J.: Anaerobic codigestion of pig manure and crude glycerol at mesophilic conditions: Biogas and digestate. Bioresource Technol. 110, 63-70 (2012). https://doi.org/10.1016/j.biortech.2012.01.080

24. Evans, P.J., Nelsen, D.A., Amador, J.C., Mcpherson, C., Parry, D.L., Stensel, H.D.: Energy recovery from food waste via anaerobic digestion. In: World Congress on Water, Climate and Energy, pp. 1-4 (2012)

25. Romelle, F.D., Ashwini, R.P., Manohar, R.S.: Chemical composition of some selected fruit peels. Eur. J. Food Sci. Technol. 4, 12-21 (2016)

26. Pardo, M.E.S., Cassellis, M.E.R., Escobedo, R.M., García, E.J.: Chemical characterisation of the industrial residues of the pineapple (Ananas comosus). J. Agric. Chem. Environ. 03, 53-56 (2014). https://doi.org/10.4236/jacen.2014.32B009

27. Lukitawesa, W.R., Millati, R., Taherzadeh, M.J., Niklasson, C.: Effect of effluent recirculation on biogas production using twostage anaerobic digestion of citrus waste. Molecules 23, 3380 (2018). https://doi.org/10.3390/molecules 23123380

28. Morais, D.R., Rotta, E.M., Sargi, S.C., Bonafe, E.G., Suzuki, R.M., Souza, N.E., Matsushita, M., Visentainer, J.V.: Proximate composition, mineral contents and fatty acid composition of the different parts and dried peels of tropical fruits cultivated in Brazil. J. Brazil Chem. Soc. 28, 308-318 (2016). https://doi. org/10.5935/0103-5053.20160178

29. Charbel, A.T., Trinchero, B.D., Morais, D.D., Mesquita, H., Birchal, V.S.: Evaluation of the potential of fruit peel biomass after conventional and microwave drying for use as solid fuel. Appl. Mech. Mater. 798, 480-485 (2015). https://doi.org/10.4028/ www.scientific.net/AMM.798.480

30. Carvalho, A., Fragoso, R., Gominho, J., Duarte, E.: Effect of minimizing d-Limonene compound on anaerobic co-digestion feeding mixtures to improve methane yield. Waste Biomass Valorization 10(1), 75-83 (2019). https://doi.org/10.1007/s12649-017-0048-1

31. Dias, T., Fragoso, R., Duarte, E.: Anaerobic co-digestion of dairy cattle manure and pear waste. Bioresource Technol. 164, 420-423 (2014). https://doi.org/10.1016/j.biortech.2014.04.110

32. Ning, J., Zhou, M., Pan, X., Lic, C., Lv, N., Wang, T., Cai, G., Wang, R., Li, J., Zhu, G.: Simultaneous biogas and biogas slurry production from co-digestion of pig manure and corn straw: performance optimization and microbial community shift. Bioresource. Technol. 282, 37-47 (2019). https://doi.org/10.1016/j. biortech.2019.02.122

33. Lemmer, A., Merkle, W., Baer, K., Graf, F.: Effects of high-pressure anaerobic digestion up to 30 bar on $\mathrm{pH}$ value, production kinetics and specific methane yield. Energy 138, 659-667 (2017). https://doi.org/10.1016/j.energy.2017.07.095

34. Ma, Y., Liu, Y.: Turning food waste to energy and resources towards a great environmental and economic sustainability: an innovative integrated biological approach. Biotechnol. Adv. 37, 107414 (2019). https://doi.org/10.1016/j.biotechadv.2019.06.013

35. Duan, N., Zhang, D., Lin, C., Zhang, Y., Zhao, L., Liu, H., Liu, Z.: Effect of organic loading rate on anaerobic digestion of pig 
manure: Methane production, mass flow, reactor scale and heating scenarios. J. Environ. Manag. 231, 646-652 (2019). https://doi. org/10.1016/j.jenvman.2018.10.062

36. Awasthi, M.K., Sarsaiya, S., Wainaina, S., Rajendran, K., Kumar, S., Quan, W., et al.: A critical review of organic manure biorefinery models toward sustainable circular bioeconomy: technological challenges, advancements, innovations, and future perspectives. Renew. Sust. Energ. Rev. 111, 115-131 (2019). https://doi. org/10.1016/j.rser.2019.05.017

37. Lapa N, Surra E, Esteves IA, Ribeiro R, Mota JPB (2017) Production of Biogas and bioH2-biochemical methods. In: Riazzi MR, Chiaramonti D (eds) Biofuels Production and Process Technology. CRC Press, Taylor \& Francis, Boca Raton, pp. 65-84.

\section{Affiliations}

\section{A. Azevedo ${ }^{1} \cdot$ J. Gominho ${ }^{2} \cdot$ E. Duarte ${ }^{1}[$}

1 LEAF - Linking Landscape, Environment, Agriculture and Food, Instituto Superior de Agronomia, Universidade de Lisboa, Tapada da Ajuda, 1349-017 Lisboa, Portugal
38. Ferrer I, Vázquez F, Font X (2010) Long term operation of a thermophilic anaerobic reactor: process stability and efficiency at decreasing sludge retention time. Bioresource Technol. 101(9), 2972-2980. https://doi.org/10.1016/j.biortech.2009.12.006

Publisher's Note Springer Nature remains neutral with regard to jurisdictional claims in published maps and institutional affiliations.
2 Centro de Estudos Florestais, Instituto Superior de Agronomia, Universidade de Lisboa, Tapada da Ajuda, 1349-017 Lisboa, Portugal 


\section{Terms and Conditions}

Springer Nature journal content, brought to you courtesy of Springer Nature Customer Service Center GmbH ("Springer Nature").

Springer Nature supports a reasonable amount of sharing of research papers by authors, subscribers and authorised users ("Users"), for smallscale personal, non-commercial use provided that all copyright, trade and service marks and other proprietary notices are maintained. By accessing, sharing, receiving or otherwise using the Springer Nature journal content you agree to these terms of use ("Terms"). For these purposes, Springer Nature considers academic use (by researchers and students) to be non-commercial.

These Terms are supplementary and will apply in addition to any applicable website terms and conditions, a relevant site licence or a personal subscription. These Terms will prevail over any conflict or ambiguity with regards to the relevant terms, a site licence or a personal subscription (to the extent of the conflict or ambiguity only). For Creative Commons-licensed articles, the terms of the Creative Commons license used will apply.

We collect and use personal data to provide access to the Springer Nature journal content. We may also use these personal data internally within ResearchGate and Springer Nature and as agreed share it, in an anonymised way, for purposes of tracking, analysis and reporting. We will not otherwise disclose your personal data outside the ResearchGate or the Springer Nature group of companies unless we have your permission as detailed in the Privacy Policy.

While Users may use the Springer Nature journal content for small scale, personal non-commercial use, it is important to note that Users may not:

1. use such content for the purpose of providing other users with access on a regular or large scale basis or as a means to circumvent access control;

2. use such content where to do so would be considered a criminal or statutory offence in any jurisdiction, or gives rise to civil liability, or is otherwise unlawful;

3. falsely or misleadingly imply or suggest endorsement, approval, sponsorship, or association unless explicitly agreed to by Springer Nature in writing;

4. use bots or other automated methods to access the content or redirect messages

5. override any security feature or exclusionary protocol; or

6. share the content in order to create substitute for Springer Nature products or services or a systematic database of Springer Nature journal content.

In line with the restriction against commercial use, Springer Nature does not permit the creation of a product or service that creates revenue, royalties, rent or income from our content or its inclusion as part of a paid for service or for other commercial gain. Springer Nature journal content cannot be used for inter-library loans and librarians may not upload Springer Nature journal content on a large scale into their, or any other, institutional repository.

These terms of use are reviewed regularly and may be amended at any time. Springer Nature is not obligated to publish any information or content on this website and may remove it or features or functionality at our sole discretion, at any time with or without notice. Springer Nature may revoke this licence to you at any time and remove access to any copies of the Springer Nature journal content which have been saved.

To the fullest extent permitted by law, Springer Nature makes no warranties, representations or guarantees to Users, either express or implied with respect to the Springer nature journal content and all parties disclaim and waive any implied warranties or warranties imposed by law, including merchantability or fitness for any particular purpose.

Please note that these rights do not automatically extend to content, data or other material published by Springer Nature that may be licensed from third parties.

If you would like to use or distribute our Springer Nature journal content to a wider audience or on a regular basis or in any other manner not expressly permitted by these Terms, please contact Springer Nature at

onlineservice@springernature.com 